\title{
EXPLORING METAPHOR AS AN ALTERNATIVE MARKETING LANGUAGE
}

Contact author:

Dr Ian Fillis

Department of Marketing

University of Stirling

Stirling

Scotland

FK9 4LA

Email: i.r.fillis@stir.ac.uk
Associate Professor Ruth Rentschler

Bowater School Management \&

Marketing

Deakin University

221 Burwood Highway

Burwood 3125 Australia 


\title{
EXPLORING METAPHOR AS AN ALTERNATIVE MARKETING LANGUAGE
}

\begin{abstract}
:
Purpose - The main aim of this paper is to stimulate more relevant and critical ideas about marketing and the wider management field by exploring the actual and potential contribution of metaphor to marketing theory and practice. The subsequent connections made can help contribute towards understanding and coping with the theory/practice gap.

Methodology/Approach - To date, the majority of metaphor application has tended to be literal and surface-level rather than theoretically grounded. This paper interrogates the literature surrounding metaphor in marketing and management fields, while also examining the contribution of other areas such as art. The paper constructs and debates the conceptual notion of the marketer as an artist.

Research Limitations/Implications - Incorporation of theoretically grounded metaphors into marketing theory can help develop a form of marketing which is capable of dealing with ambiguity, chaotic market conditions, creative thinking and practice.

Originality/Value of paper - Adoption of a metaphorical approach to marketing research helps to instil a critical and creative ethos in the research process. Marketers are concerned with identification and exploitation of opportunities. Metaphor assists in the process by enhancing visualisation of these future directions. We live out our lives to a large degree through the making of metaphorical connections. We should therefore embrace more qualitative, creative associations in marketing theory, as well as practice.
\end{abstract}

KEYWORDS: Metaphor, Theory, Marketing, Management, Art

TYPE OF MANUSCRIPT: Conceptual paper 


\section{INTRODUCTION: THE THEORY/PRACTICE GAP IN THE MANAGEMENT AND MARKETING ACADEMIES}

The main purpose of this paper is to move beyond the widespread linear/rational mode of thinking which permeates marketing and the wider management and organisation field through the stimulation of more relevant and critical ideas surrounding metaphor. A number of commentators are now questioning the approaches taken in studying management (Carroll and Gillen 1987; Whitley 1984a; 1984b). Reed (1984:279) calls for ‘a substantial reconsideration of the conceptual equipment through which management on a theoretical, methodological and empirical level is to be understood'. This reconsideration can be assisted by the evaluation of philosophical positions such as scientific realism (Putnam 1975, MacKinnon 1979; Healy and Pery 2000). Its various subdivisions include classical realism which sees the world as existing independently of its being perceived, fallibilistic realism which views science as capable of developing genuine knowledge about the world despite the fact that it will never be known with certainty and critical realism which posits that knowledge claims must be critically evaluated and tested in order to determine the extent to which they represent the world. The only real difference between the application of scientific realism to marketing and the hard sciences is that the majority of concepts presented in marketing thought are intangible, compared to the tangibles found in the sciences (Hunt 1990).

The investigation of metaphor as a legitimate avenue of investigation in marketing is situated within the wider movement of critical, creative, postmodern, aesthetic and artistic ways of knowing which are now being advocated as alternatives to mainstream ways of addressing our knowledge concerning marketing phenomena involving organisations and consumers. The impact of postmodern thinking in management and organisation studies, for example, has resulted in a 
shift in thinking from a rational approach to finding solutions to the problemising of answers (Lyotard 1984). Rather than believing in the existence of one single true solution to a particular problem, increasing numbers of researchers now believe in the possibility of a number of potential alternative directions, often involving qualitative rather than quantitative approaches. Postmodernism has freed organisation studies from the assumptions of scientific development and facilitated interaction with 'new to management' influences such as linguistics and aesthetics Gagliardi 1996), metaphor (Grant and Oswick 1996), theatre (Mangham and Overington 1987) and jazz (Weick and Westley 1996).

It is hoped that, since both managers and academics often think in metaphorical ways, as do human beings generally, a narrowing of the theory/practice gap can be obtained. The application of metaphor has tended to be literal and shallow rather than as a consequence of in-depth theoretical grounding. By interrogating the literature surrounding metaphor in the marketing and management fields, and examining the contribution of other domains such as art which has incorporated metaphor for a considerable time, a greater appreciation of a range of impacting constructs can be obtained (Harrison and Wood 1992; Harrison et al 2000). The discussion is further extended by examining the notion of the marketer as an artist, a connection which is both metaphorical and practical since much marketing is artistically based rather than founded on scientific principles (Fillis 2005). Adoption of metaphor in marketing and management theory can help to deal with contemporary aspects of the business environment such as ambiguity, chaotic market conditions and creative thinking while also introducing both a critical and creative aspect to the process. 
This special issue calls for the consideration of the relationship between theory and practice in management and allows us to think deeply about the gap, real or otherwise (Hatchuel, A. 2001; Weick 2001; Ankers and Brennan 2002). Starkey and Madan (2001) believe that management research is often guilty of a lack of relevance to managerial practice and that its disciplinary base is too narrow. The gap is also apparent across the wider social sciences where academic knowledge tends not to be utilised by the intended user (Knorr 1977; Gronhaug and Haukedal 1997; Slocum 1997; Hodgkinson et al. 2001). There is a history of critical management research which offers a range of alternative ways in which to position and theorise about management (Jacques 1992; Alvesson and Wilmott 1992; Knights 1992; Fournier and Grey 2000; Grey and Wilmott 2005) but there is a much smaller body of critical marketing research. That which does exist focuses largely, but not exclusively on consumer research (Murray and Ozanne 1991; Catterall et al. 1999; Catterall et al. 2000; Burton 2001). However, critical marketing management research is largely absent. A number of reasons have been offered in explaining this disparity, including the preservation of linear/rational business school doctrine.

Other areas of management research have long moved on from this mode of thinking and yet marketing continues to draw on theory which is outdated, or that never really explained practice in the first place. This paper attempts to address the theory/practice gap by examining the marketing theory/practice gap and constructing an alternative platform on which to understand contemporary marketing practice (Sheth and Sisodia 1999; Calder and Tybout 1999; Cunningham 1999; Ottesen and Gronhaug 2004; Pavia 2006). One curious conundrum within this gap is that many academics embrace complexity while practitioners do not, even though they often operate in such an environment. 
Management researchers should perhaps be less concerned with scientific validity and become more focused on the pursuit of relevance (Cornelissen 2002; Griseri 2002; Das 2003; Brennan and Ankers 2004; Katsikeas et al. 2004). Today's hostile business environment requires more creative and non-linear strategies, rather than the call by many in the Academy for the continued application of existing marketing techniques (Baker and Erdogan 2000). Baker (2001) believes that the theory/practice gap in marketing is widening due to the inability of marketing academics to relate their research to practice. In many cases, marketing researchers may think they are pursuing relevant activities, but in reality the recommendations they make are often flawed due to inaccurate assumptions based on linear thinking. However, Levy (2002) feels differently, believing that the gap is here to stay and we must live with it while Wensley (2002) concludes that the gap has been misdiagnosed and that in reality the domains of theory and practice are heterogeneous and overlapping.

Interest in this gap or divide is continuing, as evidenced by recent special issues of Marketing Intelligence and Planning; for example, Stringfellow et al. (2006) evaluate the relevance of marketing education to marketing practice, in particular focusing on what marketing undergraduates are actually taught by marketing academics versus what marketing practitioners would like them to know and subsequently transfer into tangible working skills. This debate is ongoing in a number of other countries including the USA and France (Narayandas et al. 1998; Shuptrine and Willenborg 1998; Kumar and Usunier 2001). A major contributor to the perpetuation of the theory/practice gap is the usefulness and readability of journal articles to practitioners (Laconia 2003; Zinkhan 2003). Crosier (2003) surveyed four hundred and seventy five articles in fourteen journals and, using the Flesch Reading Ease measurement technique 
(Flesch 1948), found that the average score was in the middle of the 'difficult' range, a further indication of the lack of engagement between academic and practitioner. Perry et al. (2003) do, however, provide a valuable link between marketing theory and practice by considering the merits of joining a conversation between the various interested parties, including both academics and practitioners.

Tapp (2004) believes that the academic marketing community should be prepared to develop closer working relationships with practitioners, rather than maintain a certain distance. There are faults on both sides of the divide, with marketing researchers often engaged in abstract quantitative activities and practitioners failing to make use of marketing journals which often contain useful material for the manager (McKenzie et al. 2002). One of the main causes of the maintaining of the theory practice gap is the continuation of the lack of understanding surrounding marketing implementation (Meldrum 1996). There has also been a call for the reevaluation of the marketing concept and the way in which marketing is taught (McCole 2004).

What, perhaps, is needed is an improvement in communications between the academic and the practitioner, although there are merits in maintaining academic objectivity over the pressures of marketing management practice (Brennan 2004). A move towards trans-disciplinary, problemcentred research has been called for, under what has been termed a shift from mode 1 to mode 2 knowledge production (Gibbons et al. 1994; Hodgkinson 2001). This trans-disciplinarity fits well with the focus of this paper on the use of metaphor in marketing, management studies, art and other areas in order to obtain novel reconceptualisations. The paper also sits well with the call by Vargo and Lusch (2004) for a new dominant logic for marketing where the conventional focus on 
tangible resources, embedded value and transactions is being superseded by a revised logic which concentrates on intangible resources, the co-creation of value and the importance of relationships.

\section{METHODOLOGIES, PARADIGMS AND MANAGEMENT RESEARCH KNOWLEDGE}

Laing (1967) highlighted the inadequacies of positivism and its focus on causal relationships. The causal model was originally intended to apply only to subject matter in the natural sciences such as animals and physical objects but this has subsequently been appropriated by researchers in the social sciences in their investigation of human subjects. An examination of the methodologies adopted in management research, however, indicates an adoption of a growing number of qualitative methods over their quantitative counterparts (Gummesson 2000; Boje 2001; Prasad and Prasad 2002). This is, in part, due to the failure of quantitative techniques to contribute to any great extent to new theory development (Cassell and Symon 2006). In fact, some commentators believe that the findings generated from qualitative research may be more relevant to management practitioners than that generated from more traditional, quantitative, approaches (Cassell et al. 2006).

All research approaches have been deemed imperfect, from experimental research design, action research and surveys to ethnography, so the continued dominance of one approach over another seems even more questionable than before (Gill and Johnson 1997). Quantitative approaches tend to centre around the testing of predetermined hypotheses and the posing of often rigid questions, with an inbuilt inability to react to changes, and hence opportunities, during the process of data collection. Genuine creative input into the process is limited, save perhaps for some initial conceptualisation following analysis of perceived relevant literatures. The inflexibility built into 
much quantitative method does not allow for spontaneous and tangential thinking once the data collection process has commenced. The adoption of qualitative methodologies enables the researcher to react to situation specific circumstances and, through experience, will be able to prompt and probe around specific questions and themes which would otherwise remain unaddressed in survey work which tends to follow standardised procedures (Donnellan 1995). Quantification of data also often conveys the notion that it is somehow irrefutable, even though the research design may have been poorly constructed with inappropriate statistical tests carried out. Bias problems may also occur due to the inclusion of leading questions and the use of small samples or there may even be an underlying hidden research agenda on the part of the researcher (Fillis 2003; Fillis and Herman 2005). This then raises the question of whether or not any research programme can be truly objective. If this is shown not to be the case, then other, more subjective approaches are surely just as acceptable.

Although in methodological terms they are full of rigour, quantitative approaches tend to ensure a body of work which replicates rather than contributes to new theory development. Marketing, for example, still tends to be shaped by the linear-rational thinking associated with the rationalist, functionalist epistemological paradigm (Carr 1999; Rutgers 1999). However, a shift in emphasis from decision making to discourse can be detected, with management now being viewed as a process of social construction involving small talk and conversation (Sjostrand et al. 2001). Howorth et al (2005) promote the need for critical perspectives as a way of stepping beyond the functionalist paradigm. This criticality can be assisted by reaching outside existing boundaries of management thinking by interrogating, for example, the arts and humanities (Guillet de Monthoux 2004). Given the knowledge limitations in many existing marketing paradigms (Brownlie et al. 1994; 1998), there has been increasing interest in the use of more creative 
approaches to understanding marketing (Brown and Patterson 2000). There has been some emphasis, for example on looking at marketing and the wider management discipline from an artistic rather than scientific perspective (Conger 1992).

\section{The Adoption of Metaphor in Management and Organisation Research}

This paper explores the use of metaphorical language as an aid to overcoming the language barriers between marketing theorists and practitioners. Differences in academic and practitioner cultures serve to create a tension between the two (Dierdonck et al. 1990). A creative way of overcoming the tension between deriving management theory and visualising management practice is through the adoption of metaphor as a means of rationalising the uncertainty involved (Heracleous 2003; Cornelissen 2006a; Cornelissen 2006b). Richardson (1994) identifies subtle differences between metaphor (the understanding of one thing in terms of another), comparison and analogy (forming an agreement or identifying a similarity following the process of reasoning from parallel cases). One way of differentiating between metaphor and analogy is through the application of domain incongruence (Tsoukas 1991) where a particular word possesses different meanings in the source and target domains (Ortony 1979). Cornelissen et al. (2005) review the literature on the organisational metaphor and identify several trends which hold increasing importance in the study of organisations. They note a developing interest in paradigms and their associated concepts which shape the field (Barley and Kunda 1992), heightened interest in organisational theorising (Weick 1989) and a focus on the nature of language through its ability to represents organisational life, including the occurrence and function of metaphor (Daft and Wiginton 1979; Cohen and Levinthal 1990; Oswick et al. 2002). These trends indicate an increase in the impact of metaphor on organisational theory. 
The word 'metaphor' is derived from the Greek 'metapherein' where meaning is carried over, or transferred, from one concept to another. Metaphorical language functions through its ability to establish original and creative connections between two concepts which then enable us to form semantic leaps between domains. Examples of metaphorical connections in organisation studies include the visualisation of organisations as anarchies, seesaws, orchestras, savage tribes, market places, organic systems, theatres, human beings and machines (Cornelissen et al. 2005). Other organisational researchers have created metaphorical connections with the fields of chaos (Thietart and Forgues 1995) and jazz (Zack 2000), while also promoting the notion of the identity and mind of the organisation (Gioia et al. 2000; Weick and Roberts 1993). Some of these metaphorical descriptions convey positive imagery while others convey negative connotations. The way in which metaphor association works involves a large amount of intangible associative thinking. Hunt and Menon (1995:82) see it as:

A literally false, declarative assertion of existential equivalence that compares two concepts or things, where one concept, called the primary concept... is claimed to be another, the secondary concept.

The metaphor is utilised as a non stringent comparison between two factors which results in a new, perhaps abstract, meaning which did not previously exist (Morgan 1980). Metaphor has been viewed as a qualitative research technique which is capable of producing statements of similarity as well as a hypothesis of comparison between diverse concepts (Koro-Ljundberg 2001; Cornelissen 2003). In order to ensure an element of rigour when using metaphor, Van den Bulte (1994) suggests that several metaphors for the same phenomena should be explored. This approach allows for the offsetting of each metaphor's own strengths and weaknesses while also following the ethos of the data triangulation process (Jack and Raturi 2006). 
There is no clear notion of 'best practice' in the application of metaphor since we either utilise existing metaphors or construct new associations which are subjective evaluations of apparent connections. In other words, some individuals will see similar associations while others will identify different relationships. This is, of course, a fundamental part of the subjective nature of qualitative research generally. Hunt and Menon (1995) and Goodwin (1996) construct useful frameworks for the analysis of metaphor in marketing and these can be used as starting points for further research in this area and in helping to establish best practice with respect to processing metaphorical data. Also, we should endeavour to avoid the overuse of specific metaphors so that their application does not become 'frozen' (Brown 1977). We should therefore seek to construct more novel metaphorical connections both within and across domains. Another issue is the ability of metaphor to transcend cultures and languages; for example, how meaningful a metaphor originally constructed in the English language will be to a native German speaker. However, a number of authors have reported on successful approaches to cross-cultural metaphor adoption across language and cultural domains (Callies and Zimmermann 2002; Zimmermann 2005; Zimmermann 2006), suggesting that any initial concerns can be overcome; for example, the adoption of the art metaphor indicates that the language of art and its inherent metaphors is capable of transcending a number of communication barriers (Khatena ad Khatena 1990; Schweik 1996; Fletcher 2005). This type of approach supports the call by Cornelissen (2003) for more theoretically grounded thinking when constructing and applying metaphor.

Cornelissen (2006b) considers the operationalisation of the metaphor in terms of target and source domains. The effectiveness of the metaphor is achieved through its ability to deal with within-domains similarity and between domains distance. From marketing and wider business perspectives, related domains might include chaos, evolution and ecology (Aldrich 1999; 
Eisenhardt and Bhatia 2002). Also, metaphors have been used to articulate ideas as an alternative to the continued adoption of more formal normative language (Richardson 1991). The main role of metaphor in marketing is to stimulate creative thinking and practice by connecting two or more spheres which may previously have never been linked either directly or indirectly (McWilliam and Dumas 1997). Ultimately, what we are interested in is deriving a form of language which can be understood by the practitioner and researcher alike. While marketers identify the origins of metaphor in services marketing (Goodwin 1996; Bremer and Lee 1997), there is little discussion of marketing metaphor within marketing management. Unlike the wider management and organisation studies domain, marketing has suffered from a neglect of sociological, legal and alternative theory influences, leading to an impoverished and static discipline. There is a clear need for a reinvigoration of the field through the adoption of more creative, theoretical and practical inputs. This reinvigoration can be assisted through the engagement of the technology transfer process where communication between the Academy and the commercial world can be improved through the understanding and practice of the technology transfer process and its ability to make academic use of qualitative data from practitioners as well as the transmission of results from academic research to practitioners (Carson 1990; Albino et al. 2004).

Rather than academics sending unidirectional signals to practitioners and practitioners choosing not to engage with academics (and vice versa), there needs to be an understanding of the mutually beneficial relationship between the two realms. Academics can learn from practitioners and practitioners can also learn from academics. However, many choose not to, perhaps because of the often perceived inaccessibility of academic language. Interrogation of qualitative, rather than quantitative data and the use of metaphor can provide useful linkages between the two communities, often because of the narrative and often conversational aspect of the data. Carson 
and Coviello (1996) provide further assistance by calling for the promotion of artistic forms of marketing which can be readily understood by both academic and practitioner. Research carried out by the practitioner can be deemed artistic in that it is uniquely created by the individual and relates specifically to his/her company.

\section{Using Metaphor to Make Cross-Disciplinary Connections}

Inns (2002) uses metaphor to connect organisational analysis with the humanities. She notes an increasing interest within organisational studies in language and metaphor and identifies several key contributions from the literature which reflect a wider interest in the linguistic turn, or the focusing of philosophy, the humanities and other disciplines on language as constructing reality (Grant and Oswick 1996; Oswick and Grant 1996; Fairclough and Hardy 1997; Grant et al. 1998). Metaphor is viewed as a core part of language and thought and, consequently, any discipline which is concerned with the examination of human behaviour should willingly embrace it. Metaphors can be viewed as mappings which move from one conceptual domain to another and which have the capability to be used as analytical and problem solving tools (Lakoff and Turner 1989) A range of uses for the metaphor within organisational analysis can be identified, including being seen as a way of providing explanations, and as a device for deconstructing and questioning embedded assumptions. Metaphors can also be used to facilitate creative thinking (Schon 1993) and as an aid to qualitative research by allowing the researcher to access hidden perceptions and feelings (Burke 1992; Marshak 1996). Possibly one of the most effective uses of the metaphor is its ability to challenge mainstream thinking (Morgan 1996). Inns identifies a range of descriptive and critical perspectives on the organisational metaphor which indicate a rich and complex area of study (Keenoy and Anthony 1992; Chia 1996; Dunford and Palmer 1996; Hopfl and Maddrell 1996; Burgoyne and Reynolds 1997). However, the domain of 
metaphor is yet to be fully explored and incorporated into marketing and the wider body of management and organisation studies.

\section{METAPHOR IN MARKETING}

Metaphors form part of our everyday speech and influence our thought processes. They appear in fields as diverse as philosophy, accounting, organisational theory and art. There is some history of the use of metaphor in marketing research but in-depth theoretical grounding and analysis is rare. It has been used to create the notion of brand community, brand personality, relationship marketing, services marketing, marketing strategy, marketing research and in describing the relationship between buyer and seller (Arndt 1985; Bernard and Adelman 1990; Winsor 1995; Fisk and Grove 1996; Goodwin et al. 1996; Rindfleisch 1996, O’Malley and Tynan 1999; Chien and Moutinho 2000; DeRosia 2001; Cornelissen 2003; Davies and Chun 2003; Dennis and Macaulay 2003; Rotfeld 2005; Sugai 2005; Celuch et al. 2006). However, researchers have tended not to build upon existing metaphor theory and largely fail to account for the shift in emphasis from a single reality to many realities, something which is essential in the metaphorical approach to understanding and knowledge development generally. Most marketing theory is not rigorously grounded in underlying metaphor theory, although surface level analogical thinking is commonplace. The central premise is straightforward: marketing theories should reflect the metaphors underlying them, since all knowledge claims are inherently metaphorical.

Interest in the use of the metaphor has been seen across most academic disciplines which are concerned with language and meaning (Gibbs 1992). There has been a growth in the number of articles, books, conferences and journals concerned with the nature and meaning of metaphor. Given this healthy level of engagement, it would seem remiss of marketing not to be engaged in 
its incorporation into theory and practice since marketers are ultimately concerned with communicating meaning. The way in which metaphors are constructed, communicated and subsequently understood can be visualised on a continuum from the point of initial comprehension, through to recognition, interpretation and appreciation. These phases are not necessarily discrete but can occur simultaneously. Sometimes, understanding is reached unconsciously, further reflecting the intangible, qualitative nature of metaphor. Given the pervasiveness of metaphor, for marketers to ignore it would be tantamount to academic and practitioner suicide:

A widely held assumption about metaphor is that people produce and understand metaphors though the juxtapositioning of disparate conceptual categories...metaphor is pervasive in everyday life, not just in language but in our structuring of experience... The way we think, what we experience, and what we do every day is very much a matter of metaphor (Gibbs 1992:594-595).

It is this juxtapositioning which is capable of producing a creative spark of an idea which may ultimately result in a new product, service or procedure.

\section{The Epistemological Role of Metaphor}

Since marketing still appears to be dominated by the empiricist world view and the logical empiricist paradigm, understanding can be enriched by investigating alternative paradigms which focus on subjective experiences. This understanding can be achieved through the application of metaphor and its use of symbols which make the intangible concrete (Morgan 1980). Metaphors have an epistemological role within marketing, as they can result in the generation of new knowledge. Meaning is constructed through application of different language, symbols and myths in a process which is highly subjective but which can also result in a way of objectifying the world: 
Words, names and ideas are used not so much to denote external things but as tools for understanding what is out there in ways that may be shared with others. Like other individuals, scientists draw on symbolic constructs to make concrete the relationships between the subjective and objective worlds...scientific activity involves viewing the world metaphorically through concepts, language, and images which focus, structure and filter the perceptions of the aspect studied. The metaphors often produce their effects by the crossing of images...(Arndt 1985:16-17).

Metaphors can be used as creative devices which are capable of suggesting research directions and contributing towards new methodologies. The incorporation of metaphors in marketing can make useful contributions towards theory and practice but the full potential for their incorporation is yet to be realised. Rather than interpreting metaphors in the literal sense, it may be more useful to view them from a theoretical perspective:

...the main function of theoretical metaphors is to stimulate the kinds of creativity that will lead to long-term, systematic, programmatic research (Hunt and Menon 1995:82).

Many existing marketing metaphors, however, are literal and surface-level rather than theoretically grounded forms which encourage the reader to investigate a particular area of literature. There is a danger of seeing metaphors everywhere so that their use becomes over inflated and their impact devalued (Black 1979). However, as long as there is some degree of theoretical grounding, either within existing marketing domains or in other areas which can usefully contribute to understanding, then their adoption can make a useful contribution to knowledge. This position is enhanced further if we consider a theory as a metaphor for viewing a phenomenon (Zaltman et al. 1982). Metaphors stimulate creativity and result in new discoveries by:

...[bringing] together two separate, apparently anomalous domains into cognitive and emotive association by using information that is directly appropriate to one as a framework of associated implications for understanding the other. These implications, suggestions, and supporting connotations, by interacting with the literal meaning of the metaphorical expression, create both cognitive and emotive tensions. Translation efforts to reduce these tensions through seeking similarities between the two domains result in comprehension 
and...permit us to view a subject matter...in an entirely new and fresh perspective...Thus, metaphors can lead to discovery through "metaphoric transfers" (Hunt and Menon 1995:83).

Creativity is stimulated by encouraging the reader to consider a metaphoric transfer of theoretical structures between the adopting discipline and the source discipline (Mirowski 1989); for example, art and marketing, art and entrepreneurship, art and entrepreneurial marketing.

\section{CONCLUSIONS AND THOUGHTS ON FUTURE RESEARCH}

This paper has offered some thoughts on the potential contribution of the metaphor in creating a more understandable and actionable language for those concerned with the theory and practice of marketing and the wider management discipline. Interrogation of the notion of metaphor encourages a more critically reflective approach to understanding marketing and other organisational issues (Alvesson and Wilmott 1992; Knights 1992; Grey and Wilmott 2005). This position also acknowledges the call for the increased use of qualitative methodologies in management research (Cassell and Symon 2006). Thinking in a metaphorical sense also helps to balance the continuing pervasiveness of linear/rational thinking. There are emerging shifts in the ways in which we visualise and interpret marketing and management with clear evidence of more creative, artistic approaches to understanding (Conger 1992; Brown and Patterson 2000). Embracing metaphor helps to deal with uncertainty, ambiguity, stress and resistance on a day to day basis, rather than dismiss it as an inconvenient outlier in the wider business environment (Morgan 1986). It also contributes towards the development of a more appropriate language for marketing theory and practice which can be readily understood by those on either side of the divide. Ultimately, it is hoped that such a stance can help to narrow the gap through the questioning of assumptions and in providing alternative explanations. 
It is recognised that much more work is needed but the earlier work of Hunt and Menon, together with research by Lakoff (1992) and Cornelissen (2003) make it possible to extend our understanding in this area. Future work could extend Hunt and Menon's frameworks by investigating further the art and artist metaphor, while simultaneously endeavouring to generate a richer set of underpinning theoretical constructs. Theory can be made more rigorous by examining the work of Lakoff and others, while also examining further the art/marketing/entrepreneurship interfaces which contain rich metaphorical data. Very little work has been carried out on the implementation of metaphor (Weick 1989). It is the juxtapositioning of the metaphor idea between and within domains and the imagery contained in the metaphor which takes it beyond the literal connection which makes it so effective in generating new research questions (Cornelissen 2003). Art imagery offers a very clear understanding since the discipline is already concerned with interpretation of image and use of metaphor. The use of metaphor is part of our everyday language (Lakoff and Johnson 1980) and appears a ready made tool which can easily be embraced in marketing. The true value of metaphor is in its ability to contribute to the theory of knowledge within marketing and the wider management academy.

\section{Improving understanding of marketing management through the art metaphor}

Commentators have been referring to the art of management for some time (Vaill 1989; Strati 1999) and many business schools are now adopting art as an input into management education. There has also been growing interest in the construction of lessons for business from artists and art organisations (Dunham and Freeman 2000; Darso and Dawids 2002), using arts based practices in business and management education (Austin and Devin 2003), the adoption of art theory to inform business strategy (Guillet de Monthoux 1996) and a call for organisation studies to learn lessons from the arts (Carr 2003; Watkins and King 2002). Not only is art present in the 
everyday life of the organisation but it is also utilised in the service of organisational goals and aspirations (Carr and Hancock 2003). Art can be used to create an epistemological framework with which to position more critical marketing management research. It has been viewed as a form of knowledge and language which uses its non-rational elements to move beyond instrumental rationality (Adorno 1970/1997). A liberating tension has been visualised between the discursive, or verbal, and the figural, or visual (Lyotard 1971). Utilising this tension in marketing management can facilitate creative thinking about the discipline, while also work towards understanding the theory/practice gap.

Table I is adapted, with additions, from Hunt and Menon (1995) to incorporate the idea of the marketer as an artist, both as a metaphor and as an operationalised construct. This conceptualisation can also be related to the notion of the owner/manager of a business as someone who is capable of managing in an artistic sense (Degot 1987; Dobson 1999; Taylor and Hansen 2005). This association permits a number of metaphorical connections to be made between marketing, the wider management field and art:

\section{Take in Table I}

The artist can be perceived not only as the creator of artistic works, but also as someone who solves problems, develops strategies and provokes society generally to think about issues that may not have been viewed as important before the production of the artistic work. The artist as owner/manager is also capable of pushing the boundaries of convention in terms of thinking about issues in new and unusual ways, in similar fashion to entrepreneurial decision makers who seek to disturb the status quo and establish new epistemological connections. 
The ontological aspect of the adapted framework refers to the elements which exist within the metaphorical structure, while the concepts are the main organising ideas which are borrowed in a metaphoric transfer. In order to be successful:

A metaphor's creative potential springs from its heuristic value, or "richness" which is largely determined by the number of substantive concepts underlying the metaphor that can be translated into concepts in marketing (Hunt and Menon 1995:85).

Richness results from the source discipline having a large body of theory which can be made relevant to marketing and other management fields. The value system of a metaphor concerns the underlying goals, motivations, objectives, ideals and aspirations. Given that there is an abundance of metaphorical usage in marketing practice, and especially within advertising, there needs to be an unusual association or connection made in order for it to stand out and be differentiated in the metaphor marketplace. The 'artist as marketer' metaphor provides a useful contribution to marketing theory and moves beyond the marketing as an art discussion. This positioning of the marketer as an artistic creator of products, services and ideas also relates to the wider consideration of the art of management (Shinn 2003; Atkinson 2004).

\section{Examples of artistic metaphors}

Interrogation of the visual arts unveils a rich source of metaphorical data which is of interest to researchers in marketing and the wider management arena. Fillis (2000) analyses the lives of a number of artists, designers and architects, including Vincent Van Gogh, Salvador Dali, Andy Warhol and Frank Lloyd Wright and constructs a number of metaphorical connections with marketing. These include the notion of the artist as both a creator of artistic works and as someone who constructs works of marketing. The artist continually seeks to solve problems of an artistic nature but he/she can also be visualised as someone who can construct an individualised 
way of knowing, based on a critical, analytical approach. The notion of artistic problem solving can then be readily transferred to the marketing domain where situation specific and sometimes non-rational approaches can provide useful alternative solutions. Outputs from these selfconstructed approaches can be viewed as a form of strategy which complement more mainstream notions such as those suggested by Doyle (2006) and which overcome issues such as uncertainty and ambiguity by embracing them rather than confining them to the periphery.

The transmutation metaphor can be used to instil an element of radicalism in marketing planning and strategy. Warhol (1975), for example, discusses the preferred type of person he wanted to work with in his artistic enterprise, the Factory. He preferred the individual to exhibit some degree of misunderstanding of Warhol's philosophy, not major discrepancies but rather a small level of misinterpretation. During the communication process, the ideas expressed by the other individual would then sometimes interact with his own in order to create a unique solution to a problem so that, instead of transmissions of the original idea, transmutations often occurred which were more creative in the longer term. This transmutation metaphor can be applied to the marketing domain where, rather than maintaining continued group consensus surrounding a particular marketing plan or strategy, members of the organisation can instead feed off each other's tangential thoughts in order to achieve meaningful marketing transmutations. This would then serve to overcome the problems experienced, for example, in new product development where over ninety percent of apparently new products are actually only extensions of existing products (Kuczmarski 1996).

The art of management refers both to the metaphorical concept of artistic management thinking i.e. managers thinking and behaving like artists, although actual management practice may not 
actually relate specifically to the adoption of artistic forms of management, and to the actual theorising and practice of management as facilitated through the understanding and practice of art within management. One of the benefits of viewing management as (an) art is the possibility of constructing an alternative epistemological framework which promotes critical thinking, rather than the perpetuation of scientific thought within the Academy. Critical thinking, of course, is also evident to a degree in positivist thinking (Desphande 1983) but researchers following this path alone are constrained by its reluctance to embrace other disciplines outside the social sciences. True creativity, however, cuts cross a number of domains and fields, some of which may relate to the original area of enquiry while others will be totally new to the researcher (Fillis and Rentschler 2006). Also, by being prepared to think about art and management in an intellectual sense can assist both managers and researchers to understand the complexities of the contemporary business environment (Ottensmeyer 1996).

Utilisation of the metaphor within a wider creative environment can also help to understand and deal with complexity in the marketing and wider business environments (Montuori 2003). The arts, rather than the sciences, have been viewed as higher ways of gaining knowledge while art itself can suggest innovative hypotheses which would otherwise be unlikely to occur through analytical scientific thinking alone (Mitroff and Kilmann 1978; Harrison et al. 1998). Art contains a claim to truth which is no less inferior to that of science (Gadamer 1975). It also provides a more complete, multidimensional and multisensory perspective to understanding, rather than focusing on explanation alone (Belk 1986). The investigation of art permits interested parties to rise above knowledge of specific issues to a more holistic plane of ideas through the relinquishing of ordinary ways of considering things. So the construction and development of the 
marketer as artist metaphor can connect with higher, or at least alternative, ways of knowing about management and marketing.

Hunt and Menon (1995) call for widespread diffusion of a particular metaphor throughout the marketing discipline. Marketing has been heavily reliant on the use of metaphors, with many being superficial and literal rather than epistemologically grounded, but this high incidence does not appear to have been questioned (Zaltman et al. 1982). Heavy use of the metaphor may be indicative of the fact that existing marketing theory has poor levels of explanatory power and that alternative avenues such as the art metaphor are needed (Darso 2004). This may also relate, as previously discussed, to the continued inability to alter the theory/practice gap. Metaphor has the potential to reinvigorate the marketing discipline by providing additional explanatory power (Nataraajan and Bagozzi 1999). There is, to date, however, a lack of theoretical justification and foundation for the use of metaphor in marketing (Fournier and Yao 1997). This is where the authors have attempted to make a creative contribution to this area by embracing ideas and practices in and of art as creative marketing metaphors, as actual data and as heuristic devices. 


\section{REFERENCES}

Adorno, T. (1997), Aesthetic Theory (R. Hullot-Kentor Trans.), University of Minnesota, Minneapolis (original work published 1970).

Albino, V., Garavelli, A.C. and Gorgoglione, M. (2004), 'Organization and technology in knowledge transfer’, Benchmarking: An International Journal, Vol.11, No.6, pp.584-600.

Aldrich, H.E. (1999), Organizational Evolving, Sage, London.

Alvesson, M and Willmott, H (eds) (1992), Critical Management Studies, Sage, London.

Ankers, P. and Brennan, R. (2002), 'Managerial relevance in academic research: an exploratory study', Marketing Intelligence and Planning, Vol.20, No.1, pp.15-21.

Arndt, J. (1985), 'The tyranny of paradigms: the case for paradigmatic pluralism in marketing," in Changing the Course of Marketing: alternative paradigms for widening marketing theory, Dholakia and Arndt (eds), JAI Press, London, pp.1-15.

Atkinson, D. (2004), 'Towards a philosophical basis for an Art of Management', Art of Management and Organisation Proceedings, Paris.

Austin, R. and Devin, L. (2003), Artful Making: What Managers Need to Know About How Artists Work, Financial Times, Prentice Hall, New York.

Baker, M.J. (2001), 'Commentary: bridging the divide', European Journal of Marketing, Vol. 35, Nos. 1/2, pp. 24-26.

Baker, M.J. and Erdogan, B.J. (2000), 'Who we are and what we do - 2000', Journal of Marketing Management, Vol.16, No.7, pp.679-696.

Barley, S.R. and Kunda, G. (1992), 'Design and devotion: surges of rational and normative ideologies of control in managerial discourse', Administrative Science Quarterly, Vol.37, pp.363400.

Belk, R. (1986,) 'Art versus science as ways of generating knowledge about materialism', in D. Brinberg and R.J. Lutz (eds), Perspectives on Methodology in Consumer Research, SpringerVerlag, New York..

Bernard, A. and Adelman, M.B. (1990), 'Market metaphors for meeting mates', in M.E. Goldberg, G. Gorn and R.W. Pollay (eds.), Advances of Consumer Research, Association of Consumer Research, Provo, UT, p. 78.

Black, M. (1979), 'More About Metaphor', in Metaphor and Thought, A. Ortony, (ed.), Cambridge University Press, Cambridge, Ithaca, NY.

Boje, D. (2001), 'Report from the division chair', Academy of Management Research Methods Decision Newsletter, Vol.16, No.2. 
Bremer, K. and Lee, M. (1997), 'Metaphors in marketing: Review and implications for marketers’, Advances in Consumer Research, Vol. 24, pp.419-424.

Brenna, R. (2004), 'Should we worry about an “academic-practitioner divide” in marketing?', Marketing Intelligence and Planning, Vol.22, No.5, pp.492-500.

Brennan, R. and Ankers, P. (2004), 'In search of relevance. Is there an academic-practitioner divide in business to business marketing?', Marketing Intelligence and Planning, Vol.22, No.5, pp.511-519.

Brown, S. (1977), The Poetics of Sociology, University of Chicago Press, Chicago, IL.

Brown, S. and Patterson, A. (eds.) (2000), Imagining Marketing: Art, Aesthetics and the Avant Garde, Routledge, Oxford.

Brownlie, D., Saren, M., Whittington, R. and Wensley, R. (1994), 'The new marketing myopia: critical perspectives on theory and research in marketing - Introduction', European Journal of Marketing, Vol. 28, No. 3, pp. 6-12.

Brownlie, D., Saren, M., Whittington, R. and Wensley, R. (1998), Rethinking Marketing, Sage, London.

Burgoyne, J. and Reynolds, M. (eds) (1997), Management Learning: Integrating Perspectives in Theory and Practice, Sage, London.

Burke, W.W. (1992), 'Metaphors to consult by’, Group and Organization Management, Vol.17, No.3, pp.255-259.

Burton, D. (2001), 'Critical marketing theory: the blueprint?', European Journal of Marketing, Vol.35, Nos.5/6, pp.722-743.

Calder, B.J. and Tybout, A.M. (1999), 'A vision of theory, research and the future of business schools’, Journal of the Academy of Marketing Science, Vol.27, No.3, pp.359-366.

Callies, M. and Zimmermann, R. (eds.) (2002), Cross-Cultural Metaphors. Investigating Domain-Mappings Across Cultures. A Project Report on the Graduate Seminar 'Metaphor in Communication and Foreign Language Teaching'. Philipps-Universität, Marburg.

Carr, A. (1999). 'Postmodernism and the turbulence in the social sciences: a brief assessment for the field of business and economics”, in D. Kantarelis (ed.), Business and Economics for the $21^{\text {st }}$ Century, Vol.3, Business and Economics Society International, Worcester, MA., pp.329-344.

Carr, A. (2003), 'Art as a form of knowledge', in Carr, A. and Hancock, P. (eds.), Art and Aesthetics at Work, Palgrave Macmillan, New York, pp.7-37. 
Carr, A. and Hancock, P. (eds.) (2003), Art and Aesthetics at Work, Palgrave Macmillan, Basingstoke, England.

Carroll, S. and Gillen, D. (1987), 'Are the classical management functions useful in describing managerial work?’, Academy of Management Review, Vol.12, pp.38-51.

Carson, D. (1990), 'Some exploratory models for assessing small firms' marketing performance (a qualitative approach), European Journal of Marketing, Vol. 24, No.1, pp.8-51.

Carson, D. and Coviello, N. (1996), 'Qualitative Research Issues at the Marketing/Entrepreneurship Interface', Marketing Intelligence and Planning, Vol.14, No.6, pp.51-58.

Cassell, C., Buehring, A., Symon, G. and Johnson, P. (2006), 'Editorial: Qualitative methods in management research: an introduction to the themed issue', Management Decision, Vol.44, No.2, pp.161-166.

Cassell, C. and Symon, G. (2006), 'Taking qualitative methods in organisation and management research seriously’, Qualitative Research in Organizations and Management, Vol.1, No.1, pp.412.

Catterall, M., Maclaran, P. and Stevens, L. (1999), 'Critical marketing in the classroom: possibilities and challenges’, Marketing Intelligence and Planning, Vol., No. 7, pp.344 - 353

Catterall, M., Maclaran, P. and Stevens, L. (2000), 'Critical reflection in the marketing curriculum’, Journal of Marketing Education, Vol.22, No.4, pp.184-192.

Celuch, K., Bantham, J.H. and Kasouf, C. (2006), 'An extension of the marriage metaphor in buyer-seller relationships: an exploration of individual level process dynamics', Journal of Business Research, Vol. 59, No.5, pp.573-581.

Chia, R. (1996). 'Metaphors and metaphorization in organizational analysis: thinking beyond the thinkable’, in D. Grant and C. Oswick (eds) Metaphor and Organizations, Sage, London.

Chien, C.S. and Moutinho, L. (2000), 'The external contingency and internal characteristic of relationship marketing', Journal of Marketing Management, Vol. 16 No.6, pp.583-595.

Cohen, W.M. and Levinthal, D.A. (1990), 'Absorptive capacity: a new perspective on learning and innovation’, Administrative Science Quarterly, Vol.35, March pp.128-152.

Conger, J.A. (1992), Learning to Lead: the Art of Transforming Managers into Leaders, JosseyBass, Sage, London.

Cornelissen, J. (2002), 'Academic and practitioner theories of marketing', Marketing Theory, Vol.2, No.1, pp.133-143.

Cornelissen, J.P. (2003), 'Metaphor as a Method in the Domain of Marketing', Psychology and Marketing, Vol. 20, No. 3, pp. 209-225. 
Cornelissen, J.P. (2006a), 'Metaphor and the dynamics of knowledge in organization theory: a case of the organizational identity metaphor', Journal of Management Studies, Vol.43, No.4, pp.683-709.

Cornelissen, J.P (2006b), Metaphor in organization theory: Progress and the past, Academy of Management Review, Vol.31, No.2, pp.485-488.

Cornelissen, J.P., Kafouros, M. and Lock, A.R. (2005), 'Metaphorical images of organization: how organizational researchers develop and select organizational metaphors', Human Relations, Vol.58, No.12, pp.1545-1578.

Crosier, K. (2004), 'How effectively do marketing journals transfer useful learning from scholars to practitioners?’, Marketing Intelligence and Planning, Vol. 22, No. 5, pp.540-556.

Cunningham, A.C. (1999), 'Confessions of a reflective practitioner: meeting the challenges of marketing's destruction', European Journal of Marketing, Vol. 33, No.7/8, pp.685-697.

Daft, R.L. and Wiginton, J.C. (1979), 'Language and Organization', Academy of Management Review, Vol.4, pp.179-191.

Darso, L. (2004), Artful Creation: Learning-Tales of Arts-in-Business, Samfundslitteratur, Frederiksberg,.

Darso, L. and Dawids, M. (2002), 'It's time for the artists to help the poor business people', Learning Lab Denmark Quarterly, October, pp.6-7.

Das, T.K. (2003), 'Managerial perceptions and the essence of the managerial world: what is an interloper business executive to make of the academic-researcher perceptions of managers?', British Journal of Management, Vol.14, No.1, pp.23-32.

Davies, G. and Chun, R. (2003), 'The use of metaphor in the exploration of the brand concept', Journal of Marketing Management, Vol. 19, Nos. 1/2, pp.45- 71.

Dennis, N. and Macaulay, M.D.R. (2003), 'Jazz and marketing planning', Journal of Strategic Marketing; Vol. 11, No.3, pp.177-185.

DeRosia, E. (2001), 'An experimental investigation of the processes underlying the interpretation of nonverbal signs and metaphors in advertising', Advances in Consumer Research, Vol. 28, No.1, p.275.

Desphande, R. (1983), 'Paradigms lost - on theory and method in research in marketing', Journal of Marketing, Vol. 47, fall, pp.101-110.

Dierdonck, R.V., Debackere, K. and Engelen, B. (1990), '’University/industry relationships: how does the Belgian academic community feel about it?’, Research Policy, Vol.19, pp.551-566. 
Dobson, J. (1999), The Art of Management and the Aesthetic Manager: The Coming Way of Business, Greenwood Press, Westport, Connecticut.

Donnellan, E. (1995), 'Changing perspectives on research methodology in marketing', Irish Marketing Review, Vol. 8, pp.81-90.

Dougherty, D. (1996), 'Organizing for innovation' in Clegg, S. R., Hardy, C. and Nord, W. R. Handbook of Organization Studies, Sage Publications, London.

Dunford, R. and Palmer, I. (1996), 'Metaphors in popular management discourse: the case of corporate restructuring”, in D. Grant and C. Oswick (eds) Metaphors and Organizations, Sage, London.

Dunham, L. and Freeman, R. (2000), 'There is no business like show business: leadership lessons from the theatre', Organizational Dynamics, Vol.29, No.2, pp.108-122.

Eisnehardt, K.M. and Bhatia, M.M. (2002), 'Organizational complexity and computation', in J.A.C. Baum (ed.), Companion to Organizations, Blackwell, Oxford, pp.442-466.

Fairclough, N. and Hardy, C. (1997), 'Management learning as discourse', in J. Burgoyne and M. Reynolds (eds.) Management Learning: Integrating Perspectives in Theory and Practice, Sage, London.

Fillis, I. (2000), 'The endless enigma or the last self portrait - implications for the future of marketing', in S. Brown and A. Patterson (eds.), Imagining Marketing: Art, Aesthetics and the Avant Garde, Routledge, London.

Fillis, I. (2003), 'A plea for biographical research as insight into smaller firm marketing theory generation', Journal of Enterprising Culture, Vol. 11, No. 1, pp. 25-45.

Fillis, I. (2005), 'A biographical study of Isambard Kingdom Brunel as insight into entrepreneurial marketing endeavour', Journal of Enterprising Culture, Vol.13, No.3, pp.223252.

Fillis, I. (2005), 'Using metaphor as an aid to creating a language for entrepreneurial and small business marketing', $10^{\text {th }}$ Academy of Marketing Annual Research Symposium on Entrepreneurial and Small Business Marketing, University of Southampton, 5- $7^{\text {th }}$ January.

Fillis, I. and Rentschler, R. (2006), Creative Marketing: an Extended Metaphor for Marketing in a New Age, Palgrave Macmillan, Basingstoke.

Fisk, R.P. and Grove, S.J. (1996), 'Applications of impression management and the drama metaphor in marketing: an introduction', European Journal of Marketing, Vol. 30, No. 9, p6-12.

Flesch, R.F. (1948), 'A New Readability Yardstick', Journal of Applied Psychology, Vol. 32, pp. 221-233. 
Fletcher, P.M. (2005), 'Consuming modern art: metaphors of gender, commerce and value in late-Victorian and Edwardian art criticism’, Visual Culture in Britain, Vol.6, No.2, pp.157-170.

Fournier, V. and Grey, C. (2000), 'At the critical moment: conditions and prospects for critical management studies’, Human Relations, Vol.53, No.1, pp.7-32.

Fournier, S. and Yao, J.L. (1997), 'Reviving brand loyalty: a reconceptualisation within the framework of consumer-brand relationships', International Journal of Research in Marketing, Vol. 14, pp. 451-472.

Gadamer, H.G. (1975), Truth and Method, Sheed and Ward, London.

Gagliardi, P. (1996), 'Exploring the aesthetic side of organisational life', in S.R. Clegg, C. Hardy and W.R. Nord (eds.), Handbook of Organization Studies,. Sage, London.

Gibbons, M., Limogoes, C., Nowotny, H., Schwartzman, P., Scott, P. and Trow, M. (1994), The New Production of Knowledge: The Dynamics of Science and Research in Contemporary Societies, Sage, London.

Gibbs, R.W. (1992), 'When is metaphor? The idea of understanding in theories of metaphor', Poetics Today, Vol. 13, No. 4, pp. 575-606.

Gioia, D.A., Schultz, M. and Corley, K.G. (2000), 'Organizational identity, image and adaptive instability’, Academy of Management Review, Vol.25, pp.63-81.

Gill, J. and Johnson, P. (1997), Research Methods for Managers, second edition, Paul Chapman Publishing Ltd, London.

Goodwin, C. (1996). 'Moving the drama into the factory: the contribution of metaphors to services research', European Journal of Marketing, Vol. 30, No.9, pp.13-36.

Goodwin, C., Grove, S.J. and Fisk, R.P. (1996), 'Collaring the Cheshire cat': studying customers' services experience through metaphor', Service Industries Journal, Vol. 16, No.4, pp.421-442.

Grant, D. and Oswick, C. (eds.) (1996), Metaphor and Organizations, Sage, London.

Grant, D., Keenoy, T. and Oswick, C. (eds.) (1998), Discourse and Organisation, Sage, London.

Grey, C. and Wilmott, H. (2005), Critical Management Studies: a Reader, Oxford University Press, Oxford.

Griseri, P. (2002), Management Knowledge: A Critical View, Palgrave, Basingstoke.

Gronhaug, K. and Haukedal, W. (1997), 'The cumbersome route from research data to knowledge use', Creativity and Innovation Management, Vol.6, No.3, pp.151-160. 
Guillet de Monthoux, P. (1996), 'The theatre of war: art, organization and the aesthetics of strategy', Studies in Cultures, Organizations and Societies, Vol.2, pp.147-160.

Guillet de Monthoux, P. (2004), The Art Firm. Aesthetic management and Metaphysical Marketing, Stanford Business Books, Stanford, CA.

Gummesson, E. (2000), Qualitative Methods in Management Research, Sage, London.

Harrison, C. and Wood, P. (eds.) (1992), Art in Theory 1900-1990: An Anthology of Ideas, Blackwell, Oxford.

Harrison, C., Wood, P. and Gaiger, J. (eds.) (1998), Art in Theory 1815-1900: An Anthology of Ideas, Blackwell, Oxford.

Harrison, C., Wood, P. and Gaiger, J. (eds.) (2000), Art in Theory 1648-1815: An Anthology of Ideas, Blackwell, Oxford.

Hatchuel, A. (2001), 'The two pillars of new management research', British Journal of Management, Vol.12, No.S1, pp.33-39.

Healy, M. and Perry, C. (2000), 'Comprehensive criteria to judge validity and reliability of qualitative research within the realism paradigm', Qualitative Market Research: An International Journal, Vol.3, No.3, pp.118-126.

Heracleous, L. (2003), 'A comment on the role of metaphor in knowledge generation', Academy of Management Review, Vol.28, pp.190-191.

Hodgkinson, G.P. (2001), 'Editorial’, British Journal of Management, Vol.12, Special Issue, S1S2.

Hodgkinson, G.P., Herriot, P. and Anderson, N. (2001), 'Realigning the stakeholders in management research: lessons from industrial, work and organizational psychology', British Journal of Management, Vol.12, Special Issue, pp.S41-48.

Hopfl, H. and Maddrell, J. (1996), 'Can you resist a dream? Evangelical metaphors and the appropriation of emotion’, in D. Grant and C. Oswick (eds) Metaphor and Organizations, Sage, London.

Howorth, C., Tempest, S. and Coupland, C. (2005), 'Rethinking entrepreneurship methodology and definitions of the entrepreneur', Journal of Small Business and Enterprise Development, Vol.12, No.1, pp.24-40.

Hunt, S.D. (1990), 'Truth in marketing theory and research', Journal of Marketing, Vol. 54, July, pp.1-15.

Hunt, S.D. and Menon, A. (1995), 'Metaphors and competitive advantage: evaluating the use of metaphors in theories of competitive strategy’, Journal of Business Research, Vol. 33, pp. 81-90. 
Inns, D. (2002), 'Metaphor in the literature of organizational analysis: a preliminary taxonomy and a glimpse at a humanities-based perspective’, Organization, Vol.9, No.2, pp.305-330.

Jack, E.P. and Raturi, A.S. (2006), 'Lessons learned from methodological triangulation in management research’, Management Research News, Vol.29, No.6, pp.345-357.

Jacques, R. (1992), 'Critique and theory building: producing knowledge 'from the kitchen', Academy of Management Review, Vol.17, No.3, pp.582-606.

Katsikeas, C.S., Robson, M.J. and Hulbert, J.M. (2004), 'In search of relevance and rigour for research in marketing’, Marketing Intelligence and Planning, Vol.22, No.5, pp.568-578.

Keenoy, T. and Anthony, P. (1992), 'HRM: metaphor, meaning and morality”, in P. Blyton and P. Turnbull (eds), Reassessing HRM, Sage, London.

Khatena, J. and Khatena, N. (1990), 'Metaphor motifs and creative imagination in art', Metaphor and Symbol, Vol5, No.1, pp.21-34.

Knights, D. (1992), 'Changing spaces: the disruptive impact of a new epistemological location for the study of management', Academy of Management Review, Vol.17, No.3, pp.514-536.

Knorr, K.D. (1977), 'Policy makers' use of social science knowledge - symbolic or instrumental', in C.H. Weiss (ed.), Using Research in Policy Making, Lexington-Heath, Lexington, KY.

Koro-Ljundberg, M. (2001), 'Metaphors as a way to explore qualitative data', International Journal of Qualitative Studies in Education, Vol.14, No.3, pp.367-379.

Kuczmarski, T.D (1996), 'Fostering an innovation mindset', Journal of Consumer Marketing, Vol. 13, No.6, pp.7-13

Kumar, R. and Usunier, J-C. (2001), 'Management education in a globalising world: lessons from French experience’, Management Learning, Vol. 32, No. 3, pp.363-391.

Laczniak, R.N. (2003). 'From the editor', Journal of Advertising, Vol. 32, No. 3, p.5.

Laing, R.D. (1967), The Politics of Experience and the Birds of Paradise, Penguin, Harmondsworth.

Lakoff, G. (1992), 'The contemporary theory of metaphor', in A. Ortony (ed.) Metaphor and Thought ( $2^{\text {nd }}$ edition), Cambridge, Cambridge University Press.

Lakoff, G. and Johnson, M. (1980), Metaphors We Live By, University of Chicago Press, Chicago.

Lakoff, G. and Turner, M. (1989), More than Cool Reason: A Field Guide to Poetic Metaphor, Chicago, University of Chicago Press. 
Levy, S.J. (2002), 'Revisiting the marketing domain', European Journal of Marketing, Vol. 36, No. 3, pp. 299-304.

Lyotard, J. (1971), Discourse/Figure, Klincksieck, Paris.

Lyotard, J-F. (1984), The Postmodern Condition: A Report on Knowledge, Manchester University Press, Manchester.

MacKinnon, E. (1979), 'Scientific realism: the new debates', Philosophy of Science, Vol.46, pp.501-532.

Mangham, I.A. and Overington, M.A. (1987), Organisations as Theatre, Wiley, Chichester.

Marshak, R.J. (1996), 'Metaphors, metaphoric fields and organizational change', in D. Grant and C. Oswick (eds.), Metaphor and Organizations, Sage, London.

McCole, P. (2004). 'Refocusing marketing to reflect practice. The changing role of marketing for business', Marketing Intelligence and Planning, Vol.22, No.5, pp.531-539.

McKenzie, C.J., Wright, S., Ball, D.F. and Baron, P.J. (2002), 'The publications of marketing faculty - who are we really talking to?', European Journal of Marketing, Vol.36, Nos.11/12, pp.1196-1208.

McWilliam, G. and Dumas, A. (1997), 'Using metaphor in new brand design', Journal of Marketing Management, Vol.13, pp.265-284.

Meldrum, M. (1996), 'Critical issues in implementing marketing', Journal of Marketing Practice, Applied Marketing Science, Vol.2, No.3, pp.29-43.

Mirowski, P. (1989), 'How not to do things with metaphors: Paul Samuelson and the science of neoclassical economics', Studies in the History and Philosophy of Science, Vol. 20, No. 2, pp. 175-191.

Mitroff, I.I. and Kilman, R.H. (1978) Methodological Approaches to Social Science, Jossey-Bass Publishers, San Francisco.

Montuori, A. (2003), 'The complexity of improvisation and the improvisation of complexity: social science, art and creativity', Human Relations, Vol.56, No.2, pp.237-255.

Morgan, G. (1980), 'Paradigms, metaphors and puzzle solving in organisational theory', Administrative Science Quarterly, Vol. 25, pp. 605-622.

Morgan, G. (1986), Images of Organization, Sage, London. 
Morgan, G. (1996), 'An afterword: is there anything more to be said about metaphor', in D. Grant and C. Oswick (eds.), Metaphor and Organizations, Sage, London.

Murray, J.B. \& Ozanne, J.L. (1991), 'The critical imagination: emancipatory interests in consumer research’, Journal of Consumer Research, Vol.19, pp129-44.

Narayandas, N., Rangan, V.K. and Zaltman, G. (1998), 'The pedagogy of executive education in business markets’, Journal of Business to Business Marketing, Vol. 5, Nos 1/2, pp. 41-64.

Nataraajan, R. and Bagozzi, R.P. (1999), 'The year 2000: looking back', Psychology and Marketing, Vol. 16, pp. 631-642.

O'Malley, L. and Tynan, C. (1999), 'The utility of the relationship metaphor in consumer markets: a critical evaluation', Journal of Marketing Management, Vol. 15, No.7, pp.587-602.

Ortony, A. (1979), 'The role of similarity in similes and metaphors', in A. Ortony (ed.), Metaphor and Thought, Cambridge University Press, Cambridge.

Oswick, C. and Grant, D. (eds.) (1996), Organisation Development: Metaphorical Explorations, Pitman, London.

Oswick, C., Keenoy, T. and Grant, D. (2002), 'Metaphor and analogical reasoning in organization theory: beyond orthodoxy’, Academy of Management Review, Vol.27, pp.294-303.

Ottensmeyer, E.J. (1996), 'Too strong to stop, too sweet to lose: aesthetics as a way to know organisations’, Organization, Vol.3, No.2, pp.189-194.

Ottesen, G.G. and Gronhaug, K. (2004), 'Barriers to practical use of academic marketing knowledge’, Marketing Intelligence and Planning, Vol.22, No.5, pp.520-530.

Pavia, T.M. (2006), 'Educating practitioners to value new marketing knowledge. A case study in executive education’, Marketing Intelligence and Planning, Vol.24, No.3, pp.296-306.

Perry, C., Carson, D., and Gilmore, A. (2003), 'Joining a conversation: writing for EJM's editors, reviewers and readers requires planning, care and persistence', European Journal of Marketing, Vol. 37, No. 5/6, pp. 652-657.

Prasad, A. and Prasad, P. (2002), 'The coming age of interpretive organizational research', Organizational Research Methods, Vol.5, No.1, pp.4-11.

Putnam, H. (1975), Mathematics, Matter and Method, Cambridge University Press, Cambridge.

Reed, M. (1984), 'Management as a social practice', Journal of Management Studies, Vol.21, No.3, pp.287-302.

Richardson, L. (1991), 'Value constituting practices, rhetoric and metaphor in sociology: a reflexive analysis', in B. Agger (ed.), Current Perspectives in Social Theory: A Reflexive Analysis, Vol.11, pp.1-15. 
Richardson, L. (1994), 'Writing a method of inquiry', in N.K. Denzin and Y.S. Lincoln (eds.), Handbook of Qualitative Research, Sage, Newbury Park, CA.

Rindfleisch, A. (1996), "Marketing as warfare: reassessing a dominant metaphor”, Business Horizons, Vol. 39, No.5, pp.3-10.

Rotfeld, H.J. (2005), 'A snapshot or a painting? Metaphors, myths, misuses and misunderstandings of marketing research information by journalists and other people who should know better', Journal of Consumer Marketing; Vol. 22, No.1, pp. 4-5.

Schon, D.A. (1993), 'Generative metaphor: a perspective on problem solving in social policy’, in A. Ortony (ed.), Metaphor and Thought ( $2^{\text {nd }}$ edn), Cambridge University Press, Cambridge.

Schweik, R. (1996), 'Painting as 'exploring' and related metaphors in $20^{\text {th }}$ century art commentary’, Metaphor and Symbol, Vol.11, No.4, pp.285-296.

Sheth, J.N. and Sisodia, R.S. (1999), 'Revisiting marketing's law like generalizations', Journal of the Academy of Marketing Science, Vol.27, No.1, pp.71-87.

Shinn, S. (2003), ‘The Creative Curriculum’, BizEd, July/August, pp.33-39.

Shuptrine, F.K. and Willenborg, J.F. (1998), 'Job experience for marketing graduates implications for university education’, Marketing Education Review, Vol. 6, No. 1, pp.225-235.

Sjostrand, S-E., Sandberg, J. and Tyrstrup, M. (eds..) (2001), Invisible management, the social construction of leadership, Thomson Learning, London.

Slocum, J.R. (1997), 'Unlearning to learn', Academy of Management Journal, Vol.40, No.6, pp.1429-1431.

Starkey, K. and Madan, P. (2001), 'Bridging the relevance gap: aligning stakeholders in the future of management research’, British Journal of Management, Vol.12, No.S1, pp.S3-S26.

Strati, A. (1999), Organization and Aesthetics, Sage, London.

Stringfellow, L., Ennis, S., Brennan, R. and Harker, M.J. (2006), 'Mind the gap. The relevance of marketing education to marketing practice', Marketing Intelligence and Planning, Vol. 24, No.3, pp. 245-256.

Sugai, P. (2005), 'Mapping the mind of the mobile consumer across borders: an application of the Zaltman metaphor elicitation technique’, International Marketing Review; Vol. 22, No. 6, pp. 641-657.

Tapp, A. (2004), 'A call to arms for applied marketing academics', Marketing Intelligence and Planning, Vol. 22, No. 5, pp.579-590. 
Thietart, R.A. and Forgues, B. (1995), 'Chaos theory and organizations', Organization Science, Vol.6, pp.19-42.

Tsoukas, H. (1991), 'The missing link: a transformational view of metaphors in organizational science', Academy of Management Review, Vol.10, No.3, pp.566-585.

Vaill, P.B. (1989), Managing as a Performing Art: New Ideas for a World of Chaotic Change, Jossey-Bass, San Francisco.

Van den Bulte, C. (1994), 'Metaphor at work', in G. Laurent, G.L. Lilien and B. Pras (eds.), Research Traditions in Marketing, Kluwer, Boston, MA.

Vargo, S.L. and Lusch, R.F. (2004), 'Evolving to a new dominant logic for marketing', Journal of Marketing, Vol.68, No.1, pp1-17.

Warhol, A. (1975), The Philosophy of Andy Warhol. From A to B and Back Again, Harcourt Brace and Company, San Diego.

Watkins, C. and King, I.W. (2002), 'Organisational performance: a view from the arts', Tamara: Journal of Critical Postmodern Organization Science, Vol.2, No.1, pp.31-46.

Weick, K.E. (1989), 'Theory construction as disciplined imagination', Academy of Management Review, Vol. 14, pp. 516-531.

Weick, K.E. (2001), 'Gapping the relevance bridge: fashions meet fundamentals in management research’, British Journal of Management, Vol.12, N0.S1, pp.S71-75.

Weick, K.E. and Roberts, K.H. (1993), 'Collective mind in organizations: heedful interrelating on flight decks’, Administrative Science Quarterly, Vol.38, pp.357-382.

Weick, K.E. and Westley, F. (1996), 'Organizational learning: affirming an oxymoron', in S.R. Clegg, C. Hardy and W.R. Nord (eds.), Handbook of Organization Studies, Sage, London.

Whitley, R. (1984a), 'The fragmented state of management studies: reasons and critiques', Journal of Management Studies, Vol.21, No., pp.331-348.

Whitley, R. (1984b), ''The scientific status of management research as a practically-orientated social science', Journal of Management Studies, Vol.21, No.4, pp.369-390.

Winsor, R.D. (1995), 'Marketing under conditions of chaos: percolation metaphors and models', Journal of Business Research, Vol. 34, No. 3, p181-189.

Zack, M.H. (2000), 'Jazz improvisation and organizing: once more from the top', Organization Science, Vol.11, pp.227-234.

Zaltman, G., Lemasters, K. and Heffring, M. (1982), Theory Construction in Marketing: Some Thoughts on Thinking, John Wiley and Sons, New York. 
Zimmerman, R. (2005), 'Cross-cultural idioms? An empirical study', in A.J. Schuth, C. Horner and J.J. Weber (eds.), Life in Language: Studies in Honour of Wolfgang Kühlwein, WVT, Trier.

Zimmermann, R. (2006), 'Metaphorical transferability', in J. Arabski (ed.), Cross-linguistic Influences in the Second Language Lexicon, Multilingual Matters, Clevedon.

Zinkhan, G.M. (2003), 'From the editor elect: a look at the future of JAMS: three years out, thirty years out', Journal of the Academy of Marketing Science, Vol. 31, No. 3, p.226. 
Table I. Dimensions of Metaphoric Transfer

\begin{tabular}{|c|c|c|c|c|c|}
\hline Metaphor & Source & Ontology & Concepts & Theories & Values \\
\hline War & $\begin{array}{l}\text { Military } \\
\text { science }\end{array}$ & $\begin{array}{l}\text { Nations, armies, } \\
\text { divisions, } \\
\text { battalions, } \\
\text { combatants, } \\
\text { allies, military } \\
\text { academies }\end{array}$ & $\begin{array}{l}\text { Strategy, tactics, } \\
\text { mission, } \\
\text { intelligence } \\
\text { deployment, } \\
\text { fortification, } \\
\text { espionage, pre- } \\
\text { emption }\end{array}$ & $\begin{array}{l}\text { Theory of } \\
\text { absolute war, } \\
\text { theory of cold } \\
\text { war, voluntary } \\
\text { theory of war, } \\
\text { Douhet theory of } \\
\text { war }\end{array}$ & $\begin{array}{l}\text { Victory, defence, } \\
\text { retaliation, duty, } \\
\text { conquest, } \\
\text { economic gain }\end{array}$ \\
\hline Game & Sports & $\begin{array}{l}\text { Teams, players, } \\
\text { coaches, } \\
\text { referees, scorers } \\
\text { audience, } \\
\text { sponsors, } \\
\text { championship }\end{array}$ & $\begin{array}{l}\text { Offence, } \\
\text { defence, co- } \\
\text { operation, team } \\
\text { spirit, score }\end{array}$ & $\begin{array}{l}\text { Zero-sum game } \\
\text { theory, finite } \\
\text { game theory, } \\
\text { infinite game } \\
\text { theory, prisoner's } \\
\text { dilemma }\end{array}$ & $\begin{array}{l}\text { Sportsmanship, } \\
\text { competition, } \\
\text { exercise, } \\
\text { pleasure, } \\
\text { relaxation, } \\
\text { release of energy, } \\
\text { physical fitness }\end{array}$ \\
\hline Organism & Biology & $\begin{array}{l}\text { Cells, humans, } \\
\text { plants, animals, } \\
\text { ecosystem, } \\
\text { genes }\end{array}$ & $\begin{array}{l}\text { Life cycle, } \\
\text { growth, } \\
\text { adaptation, } \\
\text { nutrition, } \\
\text { environment, } \\
\text { resources, } \\
\text { progress }\end{array}$ & $\begin{array}{l}\text { Evolutionary } \\
\text { theory, natural } \\
\text { selection, } \\
\text { adaptation theory }\end{array}$ & $\begin{array}{l}\text { Life, growth, } \\
\text { survival }\end{array}$ \\
\hline Marriage & $\begin{array}{l}\text { Sociology, } \\
\text { home } \\
\text { economics }\end{array}$ & $\begin{array}{l}\text { Spouses, family, } \\
\text { households, } \\
\text { children, } \\
\text { relatives, father, } \\
\text { mother, sister, } \\
\text { brother, } \\
\text { neighbour, } \\
\text { marriage }\end{array}$ & $\begin{array}{l}\text { Kinship, } \\
\text { relationship, } \\
\text { trust, } \\
\text { reproduction, } \\
\text { partners, } \\
\text { divorce }\end{array}$ & Marital theory & $\begin{array}{l}\text { Commitment, } \\
\text { love, harmony, } \\
\text { financial security, } \\
\text { procreation }\end{array}$ \\
\hline Artist & Visual arts & $\begin{array}{l}\text { Artist as creator, } \\
\text { artist as } \\
\text { owner/manager, } \\
\text { artist as problem } \\
\text { solver, artist as } \\
\text { strategy } \\
\text { formulator, } \\
\text { artist as } \\
\text { paradigm } \\
\text { creator, artist as } \\
\text { provocateur, } \\
\text { artist as } \\
\text { challenger of } \\
\text { convention, } \\
\text { pushing the } \\
\text { boundaries, } \\
\text { creating new } \\
\text { knowledge }\end{array}$ & $\begin{array}{l}\text { Strategic } \\
\text { weapon, } \\
\text { manifesto, } \\
\text { proclamation, } \\
\text { competitive } \\
\text { advantage, } \\
\text { problem } \\
\text { creating, } \\
\text { problem } \\
\text { solving, } \\
\text { challenging the } \\
\text { status quo, art } \\
\text { for art's sake, } \\
\text { artist as } \\
\text { business person }\end{array}$ & $\begin{array}{l}\text { History of art, Art } \\
\text { history } \\
\text { methodologies, } \\
\text { Experimental } \\
\text { marketing, } \\
\text { Creative } \\
\text { Marketing, } \\
\text { biographical } \\
\text { theory }\end{array}$ & $\begin{array}{l}\text { Imagination, } \\
\text { opportunity } \\
\text { creating, } \\
\text { juxtapositioning, } \\
\text { risk taking, } \\
\text { independent } \\
\text { thinking, } \\
\text { creativity as core } \\
\text { competence, } \\
\text { creative } \\
\text { philosophy }\end{array}$ \\
\hline
\end{tabular}

Adapted from Hunt and Menon (1995:84) with additions from the author 
